eCommons@AKU

THE AGA KHAN UNIVERSITY

Medical College, Pakistan

Department of Pathology and Laboratory Medicine

January 2017

\title{
Papillary craniopharyngioma: A clinicopathologic study of a rare entity from a major tertiary care center in Pakistan
}

\author{
Muhammad Usman Tariq \\ Aga Khan University \\ Nasir Ud Din \\ Aga Khan University, nasir.uddin@aku.edu \\ Zubair Ahmad \\ Aga Khan University, zubair.ahmad@aku.edu \\ Wasim Memon \\ Aga Khan University, wasim.memon@aku.edu
}

Follow this and additional works at: https://ecommons.aku.edu/

pakistan_fhs_mc_pathol_microbiol

Part of the Microbiology Commons, Pathology Commons, and the Radiology Commons

\section{Recommended Citation}

Tariq, M. U., Din, N. U., Ahmad, Z., Memon, W. (2017). Papillary craniopharyngioma: A clinicopathologic study of a rare entity from a major tertiary care center in Pakistan. Neurology India, 65(3), 570-576.

Available at: https://ecommons.aku.edu/pakistan_fhs_mc_pathol_microbiol/1088 
CPs usually have a benign clinical course, and so far, only 37 cases of ectopic recurrences (attributed to surgical contamination) have been reported. Three of these cases were PCPs which involved the frontal lobe, the contralateral temporal lobe, and the lumbosacral spine.[18] Malignancy is also a rare phenomenon, and so far only 16 cases have been reported. Thirteen of these cases were recurrent and majority of the patients had received radiotherapy. Rests of the 3 cases were de novo malignant cases.[19]

The mean overall survival was reported to be 4.8 years in recent studies, with the 5 -year survival being $88-94 \%$, and the 10 -year survival being $70-92 \%$.[5],[7] A lack of calcification, negative cerebrospinal fluid examination, tumor size less than $3 \mathrm{~cm}$, tumor diagnosis after 1995, and administration of radiotherapy, have been associated with an improved survival.[4] A recent study showed that aberrant membranous $\beta$ catenin expression is an independent factor for predicting the prognosis of CPs. [20] Jennifer et al., reported a high recurrence rate of $62 \%$, which was exclusively observed in patients with subtotal resection. [3] Complete surgical resection of CPs is often a difficult task due to their location and relation to other vital brain structures, resulting in a recurrence rate of $32 \%$ within 3 years. [4] A number of surgical techniques have been developed over the last few decades for surgical excision of CPs, and the outcome has improved, with significant reduction in recurrence rates.[7]

Postoperative morbidity has been observed in these patients due to endocrinal, neurological, and ophthalmological dysfunction as well as personality changes. Adjuvant radiotherapy is also given to the patients in whom gross total resection is not achieved, and has been demonstrated to provide better control over disease progression.[2],[3],[5],[7] Unfortunately, we had a follow up information about only 7 of our patients, and out of these, 2 developed a recurrence (due to incomplete resection) and 4 died of the disease. Additional radiotherapy was not successful in achieving disease control by either improving disease-free survival ol postoperative morbidity as 3 of 4 patients who died had also received radiotherapy and all had severe postoperative complications. A comparison of the clinicopathological features and follow up information of our study with a few other studies has been summarized in [Table 4].\{Table 4\}

Mutation in $\beta$-catenin (CTNNB 1) gene is observed in more than 70\% cases of ACPs, which is manifested by nuclear translocation of the protein and can be demonstrated by immunohistochemical stains.[10],[21], [22],[23],[24] PCPs lack this mutation but demonstrate BRAF (V600E) mutation in 95\% cases. [25] A single reported case of PCP treated with targeted therapy (vemurafenib) against this protein has shown a good control of tumor progression.[26]

\section{Conclusion}

Papillary CPs are rare neoplasms with distinct clinical and histological features. In our series, some findings were different from the published literature. These findings included a male predominance, a higher percentage of pediatric patients, a higher percentage of cases with co-existing adamantinomatous epithelium, aggressive behavior, and a poor outcome (mostly related to incomplete resection as a result of the complexity of surgery; and, proximity of the tumor to important brain structures). In depth knowledge of the histological features is necessary to avoid a misdiagnosis. Gross total resection should be attempted in every case, and strict follow up should be carried out to avoid postoperative morbidity and recurrence.

Financial support and sponsorship

Nil.

Conflicts of interest

There are no conflicts of interest.

\section{References}

Pant I, Chaturvedi S. Diagnostic approach to histopathology of central nervous system papillary tumors. Astrocyte 2014;1:124-31.

Karavitaki N, Cudlip S, Adams CB, Wass JA. Craniopharyngiomas. Endocr Rev 2006;27:371-97.

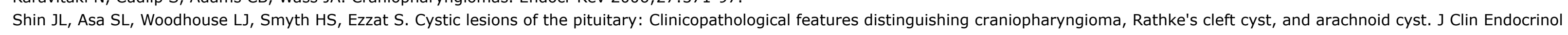




\section{Metab 1999;84:3972-82.}

Petito CK, DeGirolami U, Earle KM. Craniopharyngiomas: A clinical and pathological review. Cancer 1976;37:1944-52.

Müller HL. Childhood craniopharyngioma. Pituitary 2013;16:56-67.

Le BH, Towfighi J, Kapadia SB, Lopes MB. Comparative immunohistochemical assessment of craniopharyngioma and related lesions. Endocr Pathol 2007;18:23-30.

Fernandez-Miranda JC, Gardner PA, Snyderman CH, Devaney KO, Strojan P, et al. Craniopharyngioma: A pathologic, clinical, and surgical review. Head Neck 2012;34:1036-44.

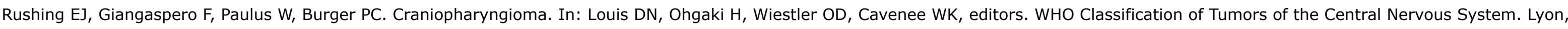

France: IARC Press; 2007. p. 238-40.

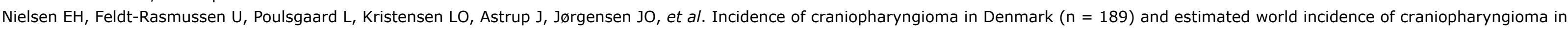
children and adults. J Neurooncol 2011;104:755-63.

Larkin SJ, Ansorge O. Pathology and pathogenesis of craniopharyngiomas. Pituitary 2013;16:9-17.

Crotty TB, Scheithauer BW, Young WF Jr, Davis DH, Shaw EG, Miller GM, et al. Papillary craniopharyngioma: A clinicopathological study of 48 cases. J Neurosurg 1995;83:206-14.

Sharma M, Mally R, Velho V, Hrushikesh K. Primary isolated cerebellopontine angle papillary craniopharyngioma. Neurol India 2012;60:438-9.

Kundu S, Dewan K, Varshney H, Das S, Mukhopadhyay S, Ghosh A. An atypical rare case of extracranial craniopharyngioma. Indian J Otolaryngol Head Neck Surg 2014;66:122-5.

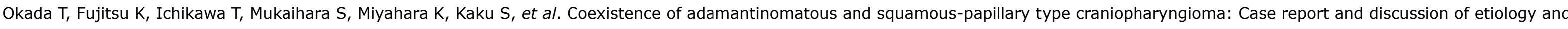
pathology. Neuropathology 2012;32:171-3.

Nishioka H, Ito H, Haraoka J, Hashimoto T, Kato Y. Repeated hemorrhage in ciliated craniopharyngioma--Case report. Neurol Med Chir 2000;40:324-8.

Xin W, Rubin MA, McKeever PE. Differential expression of cytokeratins 8 and 20 distinguishes craniopharyngioma from Rathke cleft cyst. Arch Pathol Lab Med 2002;126:1174-8.

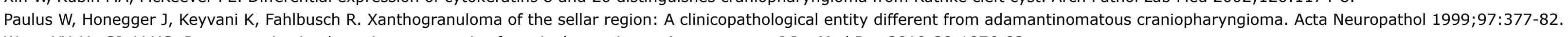
Wang XY, Xu SJ, Li XG. Post-operative implantation metastasis of craniopharyngioma: A case report. J Int Med Res 2010;38:1876-82.

Wang W, Chen XD, Bai HM, Liao QL, Dai XJ, Peng DY, et al. Malignant transformation of craniopharyngioma with detailed follow-up. Neuropathology 2015;35:50-5.

$\mathrm{Li} Z$, Xu J, Huang S, You C. Aberrant membranous expression of $\beta$-catenin predicts poor prognosis in patients with craniopharyngioma. Ann Diagn Pathol 2015; $19: 403-8$.

Adamson TE, Wiestler OD, Kleihues P, Yaşargil MG. Correlation of clinical and pathological features in surgically treated craniopharyngiomas. J Neurosurg 1990;73:12-7.

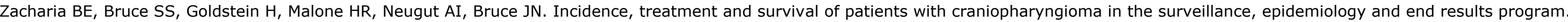
Neuro Oncol 2012;14:1070-8.

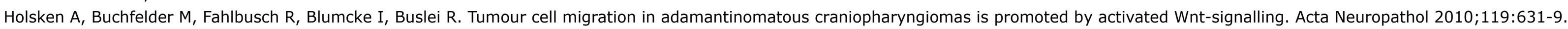

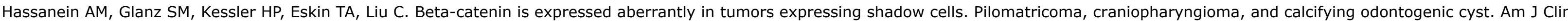
Pathol 2003;120:732-6.

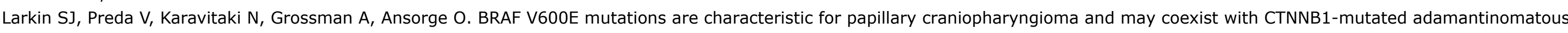
craniopharyngioma. Acta Neuropathol 2014;127:927-9.

Aylwin SJ, Bodi I, Beaney R. Pronounced response of papillary craniopharyngioma to treatment with vemurafenib, a BRAF inhibitor. Pituitary 2016;19:544-6. 